\title{
Spectrum of renal tubular damage in renal failure secondary to cirrhosis and fulminant hepatic failure
}

\author{
S. P. WILKINSON, D. HIRST, D. W. DAY, AND ROGER WILliAMS \\ From the Liver Unit, Department of Clinical Pathology, and Department of Morbid Anatomy, King's College \\ Hospital and Medical School, London SE5, UK
}

SUMMARY Measurements of urinary lysozyme were used to evaluate renal tubular integrity in 34 patients with cirrhosis or fulminant hepatic failure who had developed renal impairment. In 18 of the patients the lysozyme values were normal but in the remaining 16 were increased, supporting previous concepts that renal failure complicating hepatocellular disease may occur both without and with tubular necrosis. The lysozyme values were inversely related to the creatinine clearance, suggesting that the development of tubular necrosis may be determined by the level of renal perfusion. The validity of simpler laboratory tests often used to assess renal tubular integrity-namely, the urine sodium concentration, the urine:plasma osmolality ratio, and casts in the urine sedimentwas evaluated by comparison with the lysozyme measurements. The urine sodium concentration was of most value and the findings in the sediment were of no value at all.

Renal failure is a frequent complication of both advanced cirrhosis (Hecker and Sherlock, 1956; Vesin, 1962; Shear et al., 1965) and fulminant hepatic failure (Wilkinson et al., 1974b). In both conditions there is considerable evidence that renal tubular function and structure may or may not be maintained. Evidence for intact function includes a very low urine sodium concentration and a hyperosmolar urine, while a normal urine sediment and normal histology suggests intact structure. To denote such cases Vesin (1962) has proposed the term 'functional renal failure'. In other cases a high urine sodium concentration, an isomolar urine, large numbers of cellular or granular casts, or both, in the urine sediment and typical histological changes have all been cited as evidence for 'acute tubular necrosis'. However, the urine sodium concentration and the urine:plasma osmolality ratio are non-specific tests, casts in the sediment do not necessarily indicate tubular necrosis in jaundiced patients (Eknoyan, 1974), and the severity of renal histological changes is often poorly correlated with functional changes in acute renal failure from other causes (Finckh et al., 1962).

A more specific test of tubular integrity is the urine lysozyme concentration or clearance. Lysozyme is a low molecular weight protein (MW

Received for publication 8 August 1977
15000). Abnormal lysozymuria correlates closely with dysfunction or damage of the renal tubules, especially the proximal tubules, from a variety of causes including acute renal failure (Prockop and Davidson, 1964; Hayslett et al., 1968), cadmium poisoning (Kazantzis et al., 1963), hereditary renal tubular disorders (Barratt and Crawford, 1970), and diabetes mellitus (Farr et al., 1976). The mechanism for the lysozymuria is failure of the tubules to reabsorb what is filtered through the glomerulus.

In this study measurements of urine lysozyme were used to evaluate tubular integrity in 34 patients with renal impairment secondary to cirrhosis or fulminant hepatic failure. The results were also compared with the histological findings and the laboratory tests usually used in the differentiation of functional renal failure from acute tubular necrosis-namely, the urine sodium concentration, the urine:plasma osmolality ratio, and the presence of casts in the urine sediment.

\section{Patients and methods}

Of the 34 patients investigated 17 had histologically proved cirrhosis of the following varieties: alcoholic (9 cases), chronic active hepatitis (5), primary biliary cirrhosis (1), and cryptogenic (2). The other 17 patients had fulminant hepatic failure due to acute viral hepatitis type B (3), paracetamol overdose 
taken with suicidal intent (9), halothane-associated (3), acute fatty liver of pregnancy (1), and acute Budd-Chiari syndrome (1). All patients in the latter group had grade IV hepatic encephalopathy with markedly abnormal liver function tests. In the former group two patients with cirrhosis did not have encephalopathy, and in the remaining 15 it was of variable severity, as were the liver function tests, the serum bilirubin ranging from normal in one patient to levels as high as $1070 \mu \mathrm{mol} / 1$ in another.

In all 34 patients the creatinine clearance was $<40 \mathrm{ml} / \mathrm{min}$ and in 29 it was $<10$. In each instance the renal failure had developed spontaneously in the absence of known precipitating factors such as haemorrhage or sepsis. Although eight of the patients with cirrhosis had previously received diuretics these had been discontinued at least one week before investigation. None had shown the typical features of diuretic-induced uraemia - namely, a rising blood urea in association with too rapid a diuresis (weight loss $>0.5 \mathrm{~kg} /$ day) - and in none of them had renal function improved after diuretics were stopped.

LYSOZYME DETERMINATION

This was estimated at $37^{\circ} \mathrm{C}$ by a semi-automated modification of the assay of Litwack (1955) using an LKB reaction rate analyser (Stockholm). The reagents used were $0.067 \mathrm{M}$ phosphate buffer (pH 6.2) and $5 \mathrm{~g} / \mathrm{l}$ Micrococcus lysodeikticus dried cells (Sigma) in phosphate buffer; $10 \mathrm{mg} / 1$ phosphate buffer of hen egg-white lysozyme (Sigma) was used as a standard. Fifty microlitres of urine or plasma were diluted in $0.95 \mathrm{ml}$ of phosphate buffer and $0.15 \mathrm{ml}$ of bacterial suspension was added. The reaction, as measured by a fall in optical density at $410 \mathrm{~nm}$, was recorded for 60 seconds, but the enzyme activity was calculated from the zero-order part of the reaction curve which occurs in the first 30 seconds of the reaction for samples containing $<20$ $\mathrm{mg}$ lysozyme/l. When higher concentrations were found the samples were diluted accordingly and the reaction was repeated.

To correct for variability in the plasma concentration of lysozyme and differences in glomerular filtration rate the urine lysozyme was expressed as a fractional clearance of the endogenous creatinine clearance $\left(\frac{\text { lysozyme clearance }}{\text { creatinine clearance }} \times 100\right)$. This index has been shown to be a more sensitive measure of tubular integrity than the urine lysozyme concentration (Barratt and Crawford, 1970; Farr et al., 1976). In 21 healthy control subjects the fractional clearance of lysozyme ranged from 0 to $1 \%$, which is comparable to 0 to $1.6 \%$ calculated from the data of Harrison et al. (1973), assuming a normal creatinine clearance of $120 \mathrm{ml} / \mathrm{min}$ and a 24-hour urine volume of $1500 \mathrm{ml}$. In the control subjects the urine lysozyme concentration ranged from 0 to $5 \cdot 3$ $\mathrm{mg} / \mathrm{l}$, which is comparable to values from several other laboratories (Barratt and Crawford, 1970; Harrison et al., 1973; Farr et al., 1976).

In the patients investigated the plasma concentration of lysozyme ranged from 5.6 to $34.6 \mathrm{mg} / \mathrm{l}$, which is below the renal threshold of 40 to $50 \mathrm{mg} / 1$ reported by others (Hayslett et al., 1968; Perillie et al., 1968; Wiernik and Serpick, 1969; Harrison et al., 1973).

ASSESSMENT OF Histological CHANGES This was based entirely on renal tissue obtained after death. Renal tissue for biopsy was obtained by needle immediately after death in six of the 29 patients who died. Tissue free from postmortem autolysis was obtained at necropsy within 24 hours of death in a further 11 patients. Autolysis precluded accurate histological assessment in the remaining 12 patients.

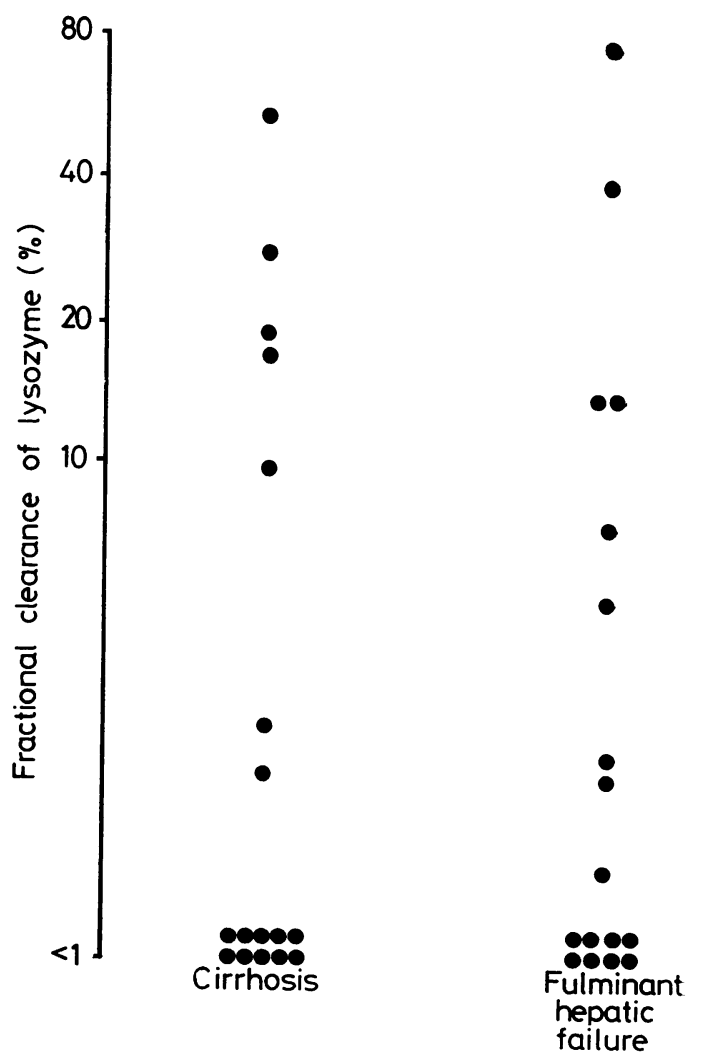

Fig. 1 Range of values for fractional clearance of lysozyme in patients with renal failure complicating cirrhosis and fulminant hepatic failure (normal range up to $1 \%$ ). 
The renal tissue was examined by light microscopy without knowledge of either the underlying liver disease or the results of the renal function studies.

A subjective evaluation for the following features of 'acute tubular necrosis' was carried out: (1) increase in number and height of the epithelial cells lining Bowman's capsule, (2) hydropic changes in the cells of the proximal tubules, (3) tubular dilatation and flattening of the tubular epithelium, (4) tubular casts, (5) interstitial oedema, and (6) the presence of nucleated cells in the vasa recta of the medulla (Heptinstall, 1974). Each of these changes was recorded as absent, slight, or marked with numerical scores of 0,1 , and 2 respectively, giving a maximum score of 12 points. The time between the lysozyme determinations and obtaining renal tissue varied from six hours to three days.

URINE SEDIMENT AND OTHER ESTIMATIONS Abnormalities in the urine sediment were quantified on a fresh specimen of urine which was centrifuged at $1000 \mathrm{~g}$ for five minutes, the supernatant poured off, and the sediment resuspended in the remaining drop of urine. This was then examined under the $10 \times 10$ microscope for granular and cellular casts and classified as no casts $(0),<1$ cast $/ 10$ fields examined $(1+)$, up to 1 cast $/ 2$ fields $(2+)$, up to 2 casts $/ 1$ field $(3+)$, and $>2$ casts $/ 1$ field $(4+)$.

Sodium, creatinine, and osmolality were determined by standard laboratory techniques.

\section{Results}

In 18 of the 34 patients the fractional clearance of lysozyme was not increased $(<1 \%)$ but the remaining 16 showed values greater than normal, ranging up to $78 \%$. A similar range of values was seen in the patients with cirrhosis as in those with fulminant hepatic failure (Fig. 1, Table). There was an inverse relationship between the lysozyme values

Table Biochemical and histological values in complete series

\begin{tabular}{|c|c|c|c|c|c|c|c|c|c|c|c|c|c|}
\hline \multirow{2}{*}{$\begin{array}{l}\text { Case } \\
\text { No. }\end{array}$} & \multirow[t]{2}{*}{ Diagnosis } & \multirow{2}{*}{$\begin{array}{l}\text { Creatinine } \\
\text { clearance } \\
(\mathrm{ml} / \mathrm{min})\end{array}$} & \multicolumn{2}{|l|}{ Lysozyme } & \multicolumn{6}{|c|}{ Histological changes } & \multirow{2}{*}{$\begin{array}{l}\text { Urine } \\
\text { sodium } \\
d \text { (mmol/l) }\end{array}$} & \multirow{2}{*}{$\begin{array}{l}\text { Urine: } \\
\text { plasma } \\
\text { osmolality }\end{array}$} & \multirow[t]{2}{*}{ Casts } \\
\hline & & & $\begin{array}{l}\text { Fractional } \\
\text { clearance } \\
(\%)\end{array}$ & $\begin{array}{l}\text { Urine } \\
\text { concen- } \\
\text { tration } \\
(m g / l)\end{array}$ & $\begin{array}{l}\text { Bow- } \\
\text { man's } \\
\text { capsule }\end{array}$ & $\begin{array}{l}\text { Hy- } \\
\text { dropic } \\
\text { changes }\end{array}$ & $\begin{array}{l}\text { Tubular } \\
\text { dilatation } \\
\text { and } \\
\text { flattened } \\
\text { epithelium }\end{array}$ & $\begin{array}{l}\text { Tubular } \\
\text { casts }\end{array}$ & $\begin{array}{l}\text { Inter- } \\
\text { stitial } \\
\text { oedema }\end{array}$ & $\begin{array}{l}\text { Nucleated } \\
\text { cells in } \\
\text { vasa recta }\end{array}$ & & & \\
\hline
\end{tabular}

\begin{tabular}{|c|c|c|c|c|c|c|c|c|c|c|c|c|c|}
\hline \multicolumn{14}{|c|}{ Cirrhosis } \\
\hline 1 & CAH & 39 & 0 & 0 & - & - & - & - & - & - & $<1$ & 1.84 & + \\
\hline 2 & Alc & 1 & 0 & 0 & - & - & - & - & - & - & 4 & $1 \cdot 18$ & $2+$ \\
\hline 3 & Alc & 3 & 0.14 & 1.6 & - & - & - & - & - & - & 10 & $1 \cdot 10$ & $2+$ \\
\hline 4 & Crypto & 3 & $0 \cdot 15$ & 0.6 & 0 & 1 & 0 & 1 & 0 & 0 & 3 & $1 \cdot 12$ & 0 \\
\hline 5 & CAH & 24 & 0.18 & $2 \cdot 9$ & 0 & 1 & 0 & 1 & 0 & 1 & 3 & $1 \cdot 17$ & + \\
\hline 6 & $\mathrm{CAH}$ & 31 & 0.28 & $3 \cdot 1$ & - & - & - & - & - & - & 4 & $1 \cdot 20$ & 0 \\
\hline 7 & Crypto & 7 & 0.30 & $3 \cdot 4$ & - & - & - & - & - & - & 4 & $1 \cdot 25$ & + \\
\hline 8 & Alc & 4 & 0.42 & 1.6 & 0 & 0 & 1 & 1 & 0 & 1 & 5 & 1.00 & + \\
\hline 9 & PBC & 7 & 0.65 & 4.0 & 1 & 1 & 0 & 2 & 0 & 1 & 6 & $1 \cdot 24$ & $4+$ \\
\hline 10 & Alc & 12 & 0.99 & $8 \cdot 5$ & 0 & 1 & 0 & 0 & 0 & 1 & 5 & 1.40 & + \\
\hline 11 & Alc & $<1$ & $2 \cdot 19$ & $4 \cdot 1$ & - & - & - & - & - & - & 26 & 1.08 & $3+$ \\
\hline 12 & Alc & $<1$ & $2 \cdot 71$ & $7 \cdot 4$ & 1 & 1 & 1 & 2 & 1 & 2 & 35 & 1.02 & $3+$ \\
\hline 13 & CAH & $<1$ & $9 \cdot 67$ & 22 & - & - & - & - & - & - & 16 & 1.02 & $4+$ \\
\hline 14 & Alc & $<1$ & 16.5 & 73 & 0 & 1 & 2 & 2 & 1 & 1 & 45 & 1.00 & 0 \\
\hline 15 & Alc & $<1$ & $18 \cdot 8$ & 11.4 & 0 & 1 & 2 & 2 & 1 & 1 & 66 & $1 \cdot 16$ & 0 \\
\hline 16 & CAH & $<1$ & $27 \cdot 6$ & 20.5 & - & - & - & - & - & - & 26 & 1.00 & + \\
\hline 17 & Alc & $<1$ & 54.0 & 22 & - & - & - & - & - & - & 14 & 1.00 & + \\
\hline \multicolumn{14}{|c|}{ Fulminant hepatic failure } \\
\hline 18 & Hal & 3 & 0.12 & $5 \cdot 0$ & $\mathbf{0}$ & 1 & 0 & $\mathbf{0}$ & $\mathbf{0}$ & 0 & 7 & $1 \cdot 18$ & 0 \\
\hline 19 & Hep B & 1 & 0.13 & $3 \cdot 8$ & - & - & 一 & 一 & - & - & 7 & 1.09 & $4+$ \\
\hline 20 & Hal & 2 & $0 \cdot 17$ & $6 \cdot 8$ & - & - & 一 & - & 一 & - & 4 & $1 \cdot 19$ & $2+$ \\
\hline 21 & Preg & 10 & 0.19 & 0.6 & 一 & - & - & 一 & - & - & $<1$ & $1 \cdot 16$ & + \\
\hline 22 & Pct & 8 & 0.20 & $0 \cdot 1$ & - & - & - & - & - & - & 1 & $1 \cdot 18$ & + \\
\hline 23 & B-C & 4 & 0.43 & 0.2 & 0 & 1 & 0 & 1 & 0 & 0 & 2 & $1 \cdot 19$ & $4+$ \\
\hline 24 & Pct & 3 & 0.54 & 0.2 & 1 & 0 & 2 & 0 & 0 & 0 & 4 & $1 \cdot 12$ & 0 \\
\hline 25 & Hep B & $<1$ & 0.71 & $2 \cdot \overline{5}$ & - & - & - & - & - & - & 11 & $1 \cdot 10$ & + \\
\hline 26 & Hal & 2 & $1 \cdot 37$ & $4 \cdot 9$ & - & - & - & - & - & - & 2 & $1 \cdot 10$ & 0 \\
\hline 27 & Pet & 3 & $2 \cdot 14$ & $12 \cdot 2$ & 0 & 1 & 1 & 0 & 1 & 0 & 22 & 1.02 & $4+$ \\
\hline 28 & Hal & $<1$ & $2 \cdot 47$ & 10.4 & 0 & 0 & 0 & 2 & 2 & 2 & 75 & 1.01 & + \\
\hline 29 & Hep B & 1 & $5 \cdot 10$ & 8.9 & 0 & 1 & 2 & 0 & $\overline{1}$ & 1 & 27 & 1.02 & $2+$ \\
\hline 30 & Pet & $<1$ & $7 \cdot 37$ & 31 & - & - & - & - & - & - & 40 & 1.02 & + \\
\hline 31 & Pet & $<1$ & $13 \cdot 8$ & 62 & - & - & - & - & - & - & 110 & 1.03 & + \\
\hline 32 & Pct & $<1$ & 14.0 & 63 & 1 & 1 & 1 & 2 & 1 & 2 & 22 & 1.03 & $3+$ \\
\hline 33 & Pct & $<1$ & 38.9 & 140 & 0 & $i$ & 0 & $\overline{1}$ & $\mathbf{0}$ & 1 & 48 & 1.02 & + \\
\hline 34 & Pct & $<1$ & $78 \cdot 0$ & 136 & 0 & 0 & 1 & 1 & 1 & 1 & 26 & 1.00 & $4+$ \\
\hline
\end{tabular}




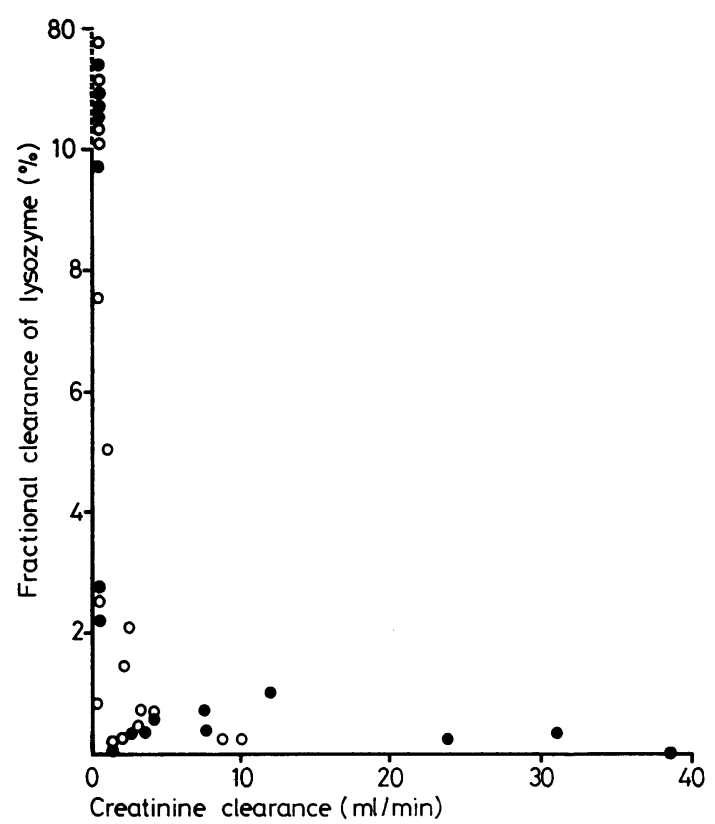

Fig. 2 Relation between endogenous creatinine clearance and fractional clearance of lysozyme ( cirrhosis; $\bigcirc$ fulminant hepatic failure). and measurements of creatinine clearance (Fig. 2). 음 Thus 14 of the 15 patients with a creatinine clearance $\vec{F}$ of $\geqslant 3 \mathrm{ml} / \mathrm{min}$ had normal lysozyme values, whereas of the 19 with a creatinine clearance of $<3 \mathrm{ml} / \mathrm{min}$ the fractional clearance of lysozyme was raised in 15 .

HISTOLOGICAL FINDINGS

Each of the different histological criteria for acute tubular necrosis was found (Table). The most $\vec{\circ}$ common was tubular casts, the least common was changes in the epithelial cells lining Bowman's cै capsule. The changes were unrelated to the cause of the liver disease. Examples are shown in Figure 3. ? The severity of the changes did not correlate with the time lapse between death and when the renal iv tissue was obtained. For example, in two patients $\overrightarrow{0}$ with the least criteria for tubular necrosis (cases 18 and 23) renal tissue was obtained at necropsy 20 and 22 hours after death respectively, whereas in two patients with florid histological changes (cases 12 T) and 15) the assessment was based on needle biopsies taken immediately after death.

For individual patients the scores ranged from one to eight points. These correlated with the $\vec{\theta}$ lysozyme results in that for patients with a normal $\infty$ fractional clearance of lysozyme the score ranged $\square$ from two to five points for cirrhosis and one to three

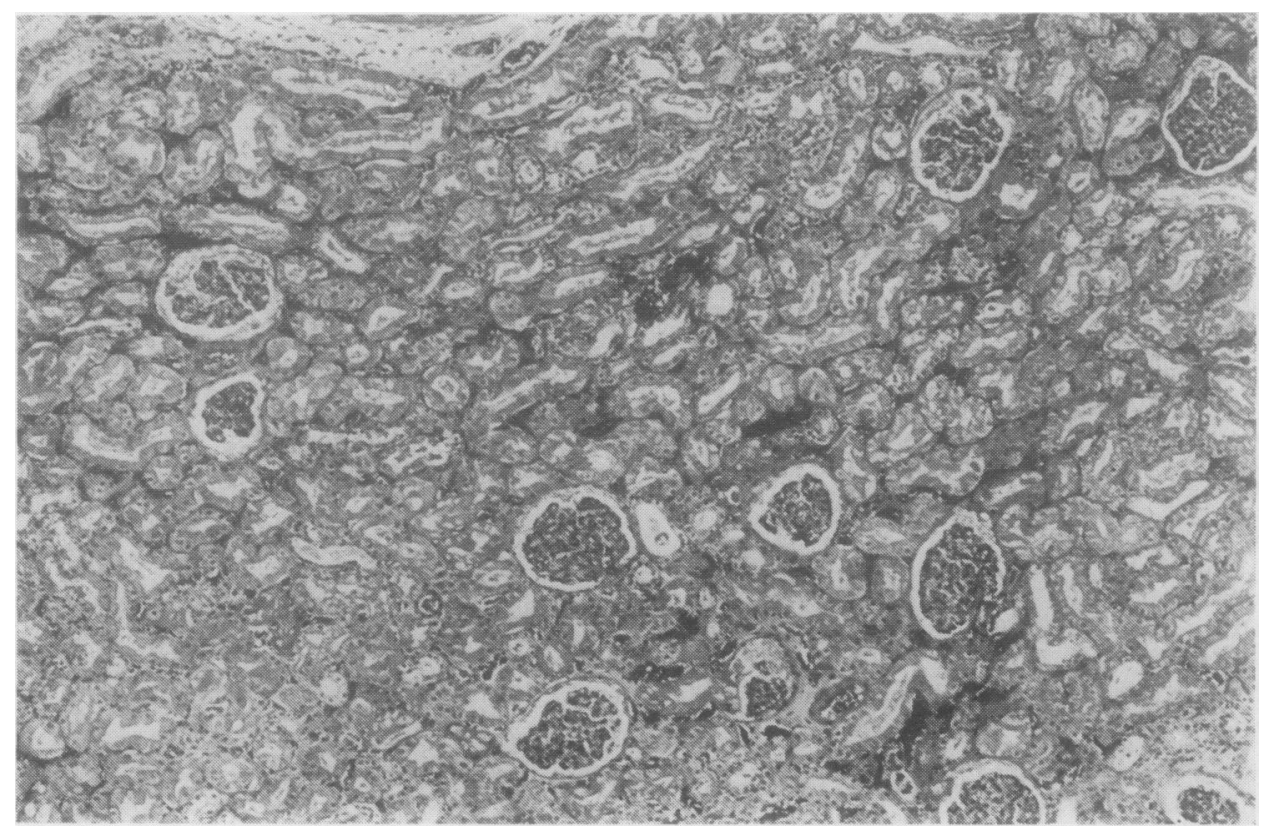

Fig. 3a 


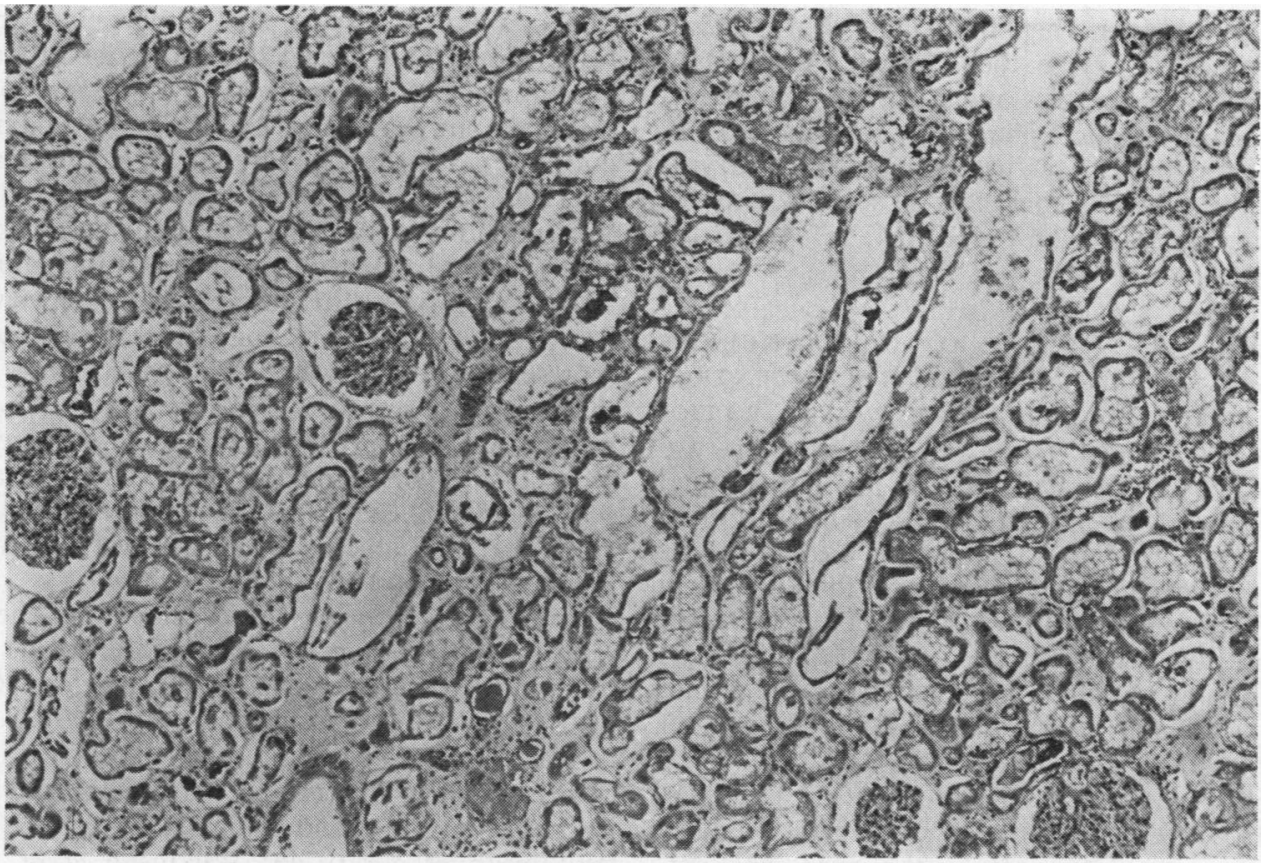

Fig. 3 Examples of renal histology. (a) Minimal changes only (case 4); (b) marked tubular dilatation and flattening of the tubular epithelium (case 14); (c) nucleated cells in vasa recta (case 32). The fractional clearance of lysozyme was normal in (a) but raised in (b) and (c). 
points for fulminant hepatic failure. For patients with a raised lysozyme the scores were seven to eight points for cirrhosis and three to eight points for fulminant hepatic failure. For the whole series the score for the patients with the normal lysozyme was significantly less than for those in whom the latter was increased $(2.6 \pm \mathrm{SE} \mathrm{0.4,5.7 \pm SE} \mathrm{0.7}$ respectively, $\mathrm{P}<0.005$ ).

RELATION OF FRACTIONAL CLEARANCE OF LYSOZYME TO URINE SODIUM CONCENTRATION, URINE:PLASMA OSMOLALITY RATIO, AND CASTS IN THE URINARY SEDIMENT

The best separation between patients with normal or raised lysozyme was obtainable using the urine sodium concentration. In the former group this was always $<12 \mathrm{mmol} / 1$ but was greater than this, with a maximum value of $110 \mathrm{mmol} / 1$, in all but one patient in whom the lysozyme was raised. Slightly less discrimination could be obtained from the urine: plasma osmolality ratio which was $>1 \cdot 10$ in 14 of the 18 patients with normal lysozyme and $<1 \cdot 10$ in 14 of the 16 others. No correlation could be detected between lysozyme values and the presence of granular or cellular casts in the urine sediment. Scores of 0 to $4+$ were found in patients with both normal and high lysozyme (Table).

\section{Discussion}

The finding of both normal and raised values for the fractional renal clearance of lysozyme supports previous concepts that in the renal failure of hepatocellular disease tubular dysfunction may or may not be a feature. The relationship between the lysozyme measurements and histological findings suggests that the tubular dysfunction is related to structural tubular damage ('acute tubular necrosis'). There are, however, limitations to the value of the histological findings reported in the present study. Ideally renal tissue should have been obtained in life at the time of the lysozyme measurements, but in a group of patients with severe hepatic disease who characteristically have a pronounced bleeding diathesis this was not considered justifiable. Although the extent of the histological changes did not appear to correlate with the time lapse between death and obtaining the tissue sample, autolytic changes, at least in some patients, cannot be excluded. Not surprisingly, minor histological changes were sometimes found in the patients with normal lysozyme values since the latter were sometimes measured up to three days before death and terminal hypotension could have accounted for the histological changes.

The inverse relationship between creatinine clearance and lysozyme was of particular interest. It suggests that one determining factor for the development of tubular necrosis is the level of renal perfusion, tubular integrity being well maintained until this is reduced to a level at which the creatinine clearance is about $3 \mathrm{ml} / \mathrm{min}$. Below this level tubular dysfunction and necrosis occurs. This finding, together with a continuous range of values for urine lysozyme, is more in keeping with the view that functional renal failure and acute tubular necrosis represent part of a spectrum of renal failure rather than separate entities. Furthermore, functional renal failure can progress to acute tubular necrosis, especially when associated with haemorrhage or septicaemia (Shear et al., 1965; Wilkinson et al., 1974b), events which would be expected further to reduce renal blood flow.

The renal vasoconstriction underlying the renal failure could be due to a circulating toxin. Endotoxins are powerful renal vasoconstrictors (Gillenwater et al., 1963; Cavanagh et al., 1970) and a number of centres have now reported a close correlation between endotoxaemia and renal failure in both cirrhosis and fulminant hepatic failure (Wilkinson et al., 1974a; Wilkinson et al., 1976; Liehr et al., 1976; Clemente et al., 1977). Evidence for Gram-negative bacterial infection has not usually been found and the endotoxaemia is most probably due to failure of the liver effectively to filter the endotoxins present in portal venous blood.

The lysozyme results were compared with the urine sodium concentration, the urine:plasma osmolality ratio, and the number of casts in the urine sediment, since these are often used to differentiate functional renal failure from acute tubular necrosis. The close agreement found with the urine sodium concentration supports its use in diagnosing the type of renal failure. The cut-off point of 12 $\mathrm{mmol} / \mathrm{l}$ is much lower than is usually found in acute renal failure not associated with liver disease, but 'intact nephrons' will be exposed to the effects of the very high plasma levels of aldosterone which are almost invariably found in patients with hepatocellular disease and renal failure. The urine:plasma osmolality ratio was less clearly related to the lysozyme measurements, but this may be because concentration of the urine is a function of the nephron beyond the proximal tubule, whereas the lysozyme clearance is more strictly a test of proximal tubular function. The presence or absence of casts in the urine sediment was of no value whatsoever. Eknoyan (1974) has pointed out that patients with jaundice without renal failure may have numerous casts in the urine.

We are grateful to the Medical Research Council 
for its continued support and to Linda Rimmer for editorial assistance.

\section{References}

Barratt, T. M., and Crawford, R. (1970). Lysozyme excretion as a measure of renal tubular dysfunction in children. Clinical Science, 39, 457-465.

Cavanagh, D., Rao, P. S., Sutton, D. M. C., Bhagat, B. D., and Bachmann, F. (1970). Pathophysiology of endotoxin shock in the primate. American Journal of Obstetrics and Gynecology, 108, 705-722.

Clemente, C., Bosch, J., Rodes, J., Arroyo, V., Mas, A., and Maragall, S. (1977). Functional renal failure and haemorrhagic gastritis associated with endotoxaemia in cirrhosis. Gut, 18, 556-560.

Eknoyan, G. (1974). Renal disorders in hepatic failure (Letter). British Medical Journal, 2, 670.

Farr, M., Wardle, E. N., and Wilkinson, K. (1976). Lysozymuria in diabetes. British Medical Journal, 1, 624-625.

Finckh, E. S., Jeremy, D., and Whyte, H. M. (1962). Structural renal damage and its relation to clinical features in acute oliguric renal failure. Quarterly Journal of Medicine, 31, 429-446.

Gillenwater, J. Y., Dooley, E. S., and Frohlich, E. D. (1963). Effects of endotoxin on renal function and haemodynamics. American Journal of Physiology, 205, 293-297.

Harrison, J. F., Parker, R. W., and De Silva, K. L. (1973). Lysozymuria and acute disorders of renal function. Journal of Clinical Pathology, 26, 278-284.

Hayslett, J. P., Perillie, P. E., and Finch, S. C. (1968). Urinary muramidase and renal disease. New England Journal of Medicine, 279, 506-512.

Hecker, R., and Sherlock, S. (1956). Electrolyte and circulatory changes in terminal liver failure. Lancet, 2 , 1121-1125.

Heptinstall, R. H. (1974). In: Pathology of the Kidney, 2nd edition, pp. 787-789. Little, Brown, Boston.
Kazantzis, G., Flynn, F. V., Spowage, J. S., and Trott, D. G. (1963). Renal tubular malfunction and pulmonary emphysema in cadmium pigment workers. Quarterly Journal of Medicine, 32, 165-192.

Liehr, H., Grün, M., Brunswig, D., and Sautter, T. (1976). Endotoxinamie bei Leberzirrhose. Zeitschrift für Gastroenterologie, 14, 14-23.

Litwack, G. (1955). Photometric determination of lysozyme activity. Proceedings of the Society for Experimental Biology and Medicine, 89, 401-403.

Perillie, P. E., Kaplan, S. S., Lefkowitz, E., Rogaway, W., and Finch, S. C. (1968). Studies of muramidase (lysozyme) in leukaemia. Journal of the American Medical Association, 203, 317-322.

Prockop, D. J., and Davidson, W. D. (1964). A study of urinary and serum lysozyme in patients with renal disease. New England Journal of Medicine, 270, 269-274.

Shear, L., Kleinerman, J., and Gabuzda, G. J. (1965). Renal failure in patients with cirrhosis of the liver. I. Clinical and pathologic characteristics. American Journal of Medicine, 39, 184-198.

Vesin, P. (1962). Late functional renal failure in cirrhosis with ascites: pathophysiology, diagnosis and treatment. In Aktuelle Probleme der Hepatologie, edited by G. A. Martini and S. Sherlock, pp. 98-109. Thieme, Stuttgart.

Wiernik, P. H., and Serpick, A. A. (1969). ClinicaI significance of serum and urinary muramidase activity in leukaemia and other haematologic malignancies. American Journal of Medicine, 46, 330-343.

Wilkinson, S. P., Arroyo, V., Gazzard, B. G., Moodie, H., and Williams, R. (1974a). Relation of renal impairment and haemorrhagic diathesis to endotoxaemia in fulminant hepatic failure. Lancet, 1, 521-524.

Wilkinson, S. P., Blendis, L. M., and Williams, R. (1974b). Frequency and type of renal and electrolyte disorders. in fulminant hepatic failure. British Medical Journal, 1, 186-189.

Wilkinson, S. P., Moodie, H., Stamatakis, J. D., Kakkar, V. V., and Williams, R. (1976). Endotoxaemia and renal failure in cirrhosis and obstructive jaundice. British Medical Journal, 2, 1415-1418. 